\title{
PENGEMBANGAN MEDIA PEMBELAJARAN BERBASIS ALAT PERAGA MAKET KUDA-KUDA SISTEM BONGKAR PASANG PADA MATA KULIAH KONSTRUKSI BANGUNAN GEDUNG III Taufiq Shidqi Romadloni ${ }^{1}$, Chundakus Habsya ${ }^{2}$, A.G. Tamrin ${ }^{3}$
}

\begin{abstract}
ABSTRAK
Tujuan penelitian ini adalah untuk: (1) Menghasilkan media pembelajaran berbasis alat peraga yang dapat dibongkar pasang untuk Mata kuliah Konstruksi Bangunan Gedung III. (2) Mengetahui tingkat kelayakan media pembelajaran berbasis alat peraga bongkar pasang pada Mata Kuliah Konstruksi Bangunan Gedung III. Penelitian ini menggunakan metode penelitian Research and Development $(\mathrm{RnD})$, dengan melakukan pengembangan media pembelajaran berbasis alat peraga bongkar pasang. Prosedur pengembangan media pembelajaran dilakukan melalui: (1) Tahap studi pendahuluan dilakukan dengan studi lapangan/observasi dan studi literature/pustaka, (2) Tahap pengembangan dilakukan dengan cara yaitu: merancang produk media pembelajaran; menyusun instrument penilaian; melakukan validasi instrument penilaian; validasi produk oleh ahli materi, ahli media dan ahli pembelajaran; memperbaiki hasil validasi produk; melakukan uji coba terbatas terhadap 6 mahasiswa angkatan 2014 PTB FKIP UNS dan uji coba luas terhadap 50 mahasiswa angkatan 2014 PTB FKIP UNS, serta mengevaluasi produk, (3) Tahap evaluasi merupakan tahap final pengembangan media pembelajaran yang berbentuk model hipotetik alat peraga bongkar pasang. Hasil penelitian dari penilaian ahli materi diperoleh persentase sebesar 86,09 \% yang dikategorikan sangat layak. Penilaian ahli pembelajaran diperoleh persentase sebesar $91,765 \%$ yang dikategorikan sangat layak. Penilaian ahli media menyatakan bahwa media pembelajaran berbasis alat peraga bongkar pasang sangat layak dengan persentase sebesar 93,571\%. Pada uji coba terbatas diperoleh persentase sebesar $63 \%$ yang dikategorikan layak. Uji coba luas menyatakan media pembelajaran sangat layak dengan persentase sebesar $84,36 \%$.
\end{abstract}

Kata Kunci: alat peraga, media pembelajaran, maket, kuda-kuda kayu

\footnotetext{
${ }^{1}$ Mahasiswa Pendidikan Teknik Bangunan FKIP UNS

${ }^{2}$ Pembimbing 1. Chundakus Habsya

${ }^{3}$ Pembimbing 2. A. G. Tamrin
} 


\title{
DEVELOPMENT OF MEDIA-BASED LEARNING PROPS SCALE MODEL TRUSS KNOCK DOWN SYSTEM ON COURSES CONSTRUCTION OF BUILDING III Taufiq Shidqi Romadloni ${ }^{1}$, Chundakus Habsya ${ }^{2}$, A. G. Tamrin ${ }^{3}$
}

\begin{abstract}
The purpose of this research is to: (1) Produce media-based learning props that can be disassembled to install the course construction of Building III. (2) know the level of appropriateness of media-based learning props unloading pairs on the courses construction of Building III. This research uses research methods Research and Development $(\mathrm{RnD})$, with the development of media-based learning props unloading pairs. Learning media development procedure done through: (1) the stage of preliminary studies done by fieldwork/observation and study of literature/libraries, (2) the development phase is done in a way that is: designing learning media products; drawing up the assessment instrument; perform validation of assessment instruments; validation products by material experts, media expert and expert learning; improve the results of the validation of the product; perform limited trials against 6 students FKIP UNS PTB 2014 force and extensive trials against 50 University students FKIP UNS PTB 2014 host, as well as evaluating the product, (3) the stage of evaluation is the final stage of the learning media development model hipotetik knock down props. The research results of the expert assessment of the material obtained the percentage of $86.09 \%$ categorized very feasible. Expert assessment of learning acquired a percentage of $91.765 \%$ categorized very feasible. Assessment of media experts stated that the media-based learning props unloading pairs of very decent with a percentage of $93.571 \%$. In limited trials retrieved the percentage of $63 \%$ are categorized. Extensive trials declared media learning very decent with a percentage of $84.36 \%$.
\end{abstract}

Keywords: learning media, props, scale model, wooden truss

\footnotetext{
${ }^{1}$ Mahasiswa Pendidikan Teknik Bangunan FKIP UNS

${ }^{2}$ Pembimbing 1. Chundakus Habsya

${ }^{3}$ Pembimbing 2. A. G. Tamrin
} 
PENDAHULUAN

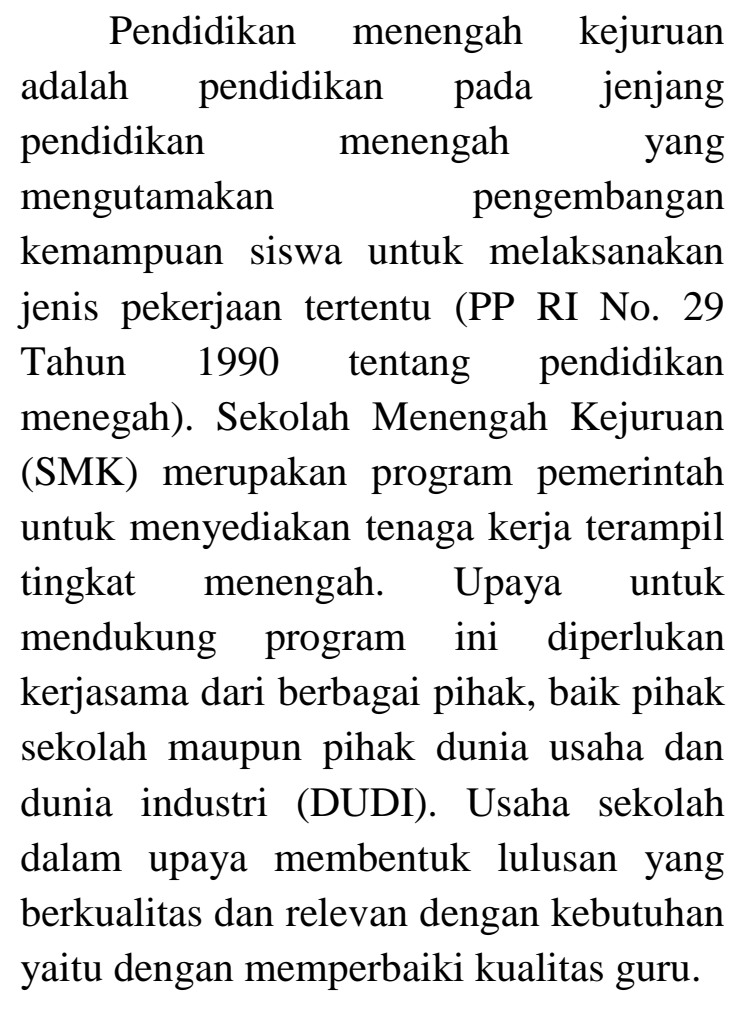

Program Studi Pendidikan Teknik Bangunan Fakultas Keguruan dan Ilmu Pendidikan Universitas Sebelas Maret Surakarta merupakan lembaga pengadaan guru atau lembaga pendidikan tenaga kependidikan (LPTK) sebagai pengembang dan penghasil tenaga pendidik yang berkarakter kuat dan cerdas dalam bidang ilmu Pendidikan Teknik Bangunan.

Dosen atau pengajar merupakan salah satu faktor yang berpengaruh terhadap proses pendidikan dan pembelajaran di kampus. Peran dosen dalam pendidikan sangat penting. Dalam budaya bangsa yang paternalistik para mahasiswa masih sangat patuh kepada dosennya. Pemegang peranan yang sangat berpengaruh terhadap mahasiswa dalam pembelajaran yaitu dosen. Gaya kebiasaan, kedisiplinan, kemampuan dan kompetensi dosen dalam proses pembelajaran sangat menentukan hasil dari proses pembelajaran itu sendiri. Untuk menjadi seorang guru diperlukan ijasah Program Profesi Guru (PPG) setelah menempuh Strata 1 Pendidikan sebagai alat ukur kelayakan seorang pendidik, akan tetapi untuk menjadi seorang dosen tidak diperlukan persyaratan kemampuan mengajar, hanya berbekal predikat jenjang strata 2 atau strata 3 dapat menjadi dosen.

Menurut data SPMB (Seleksi Penerimaan Mahasiwa Baru) UNS, jumlah siswa SMK yang diterima di program studi Pendidikan Teknik Bangunan setiap tahunnya mengalami penurunan. Pada tahun 2012 sebanyak 19 siswa SMK diterima di program studi Pendidikan Teknik Bangunan. Pada tahun 2013 mengalami penurunan, yaitu menjadi 17 siswa SMK. Selanjutnya pada tahun 2014 dan 2015 adalah sebanyak 15 dan 10 siswa SMK.

Pada tahun angkatan 2012 hanya ada 7 mahasiswa yang berasal dari SMK Teknik Bangunan. Dan 62 mahasiswa merupakan lulusan diluar SMK Teknik Bangunan. Mahasiswa yang berasal dari SMK cenderung lebih awal dalam menagkap materi perkuliahan dibandingkan dengan mahasiswa yang berasal dari nonSMK. Karena disetiap

\footnotetext{
${ }^{1}$ Mahasiswa Pendidikan Teknik Bangunan FKIP UNS

${ }^{2}$ Pembimbing 1. Chundakus Habsya

${ }^{3}$ Pembimbing 2. A. G. Tamrin
} 
Program Studi mempunyai mahasiswa yang belum tentu liniear dengan Program Studi, maka hal ini mengharuskan sistem pembelajaran pada perguruan tinggi melakukan apersepsi pembelajaran dan mengajarkan materi tentang disiplin ilmu dimulai dari dasar.

Konstruksi Bangunan Gedung III merupakan salah satu mata kuliah pada Program Studi Pendidikan Teknik Bangunan. Mata kuliah ini merupakan mata kuliah wajib yang harus ditempuh oleh mahasiswa Pendidikan Teknik Bangunan FKIP UNS, mata kuliah ini tayang pada semester empat. Mata kuliah Konstruksi Bangunan Gedung III mencakup beberapa kompetensi dasar, yaitu: 1). Mendesain denah, tampak, potongan, rencana atap, detail ramuan atap, dan situasi bangunan sederhana 1 lantai, 2). Mendesain denah, tampak, potongan, rencana atap, rencana pondasi, dan situasi bangunan sederhana 2 lantai, 3). Mendesain detail kuda-kuda, detail pondasi, detail pintu dan jendela, detail plafound, detail beton bertulang/baja pada perencanaan bangunan bertingkat, 4). Mendesain electrical, saluran air bersih, saluran air kotor, AC dan penangkal petir pada perencanaan bangunan bertingkat.

Pada kompetensi perencanaan bangunan bertingkat, salah satu permasalahan yang dapat dimunculkan adalah materi mendesain detail kuda-kuda dirasa cukup sulit untuk dipahami sebagian besar mahasiswa. Berdasarkan survey sebanyak 48 mahasiwa menganggap mendesain detail kuda-kuda merupakan hal yang sulit. Untuk mendukung mahasiswa dalam memahami bentuk kuda-kuda, dan membantu mewujudkan tujuan dan kompetensi pembelajaran, dirasa masih cukup perlu menggunakan sebuah media pembelajaran.

Tujuan dari penelitian ini adalah untuk mengembangkan media pembelajaran berbasis alat peraga pada mata kuliah Konstruksi III dan selanjutnya dilakukan mengetahui tingkat kelayakan media pembelajaran berbasis alat peraga pada mata kuliah Konstruksi Bangunan Gedung III.

Menurut Boove (Sanaky, 2009: 3) berpendapat bahwa media adalah sebuah alat yang mempunyai fungsi menyampaikan pesan, sedangkan media pembelajaran adalah sebuah alat yang berfungsi dan digunakan untuk menyampaikan pesan pembelajaran. Dari pemaparan diatas dapat diambil kesimpulan bahwa media pembelajaran merupakan suatu alat yang digunakan dalam proses kegiatan pembelajaran untuk membantu menyampaikan pesan informatif dalam bentuk visual atau verbal untuk mencapai tujuan pembelajaran.

Ruiz (Rayandra Asyhar, 2011:11) mengatakan alat peraga digunakan oleh guru untuk memberi penekanan pada informasi, memberikan stimulasi

\footnotetext{
${ }^{1}$ Mahasiswa Pendidikan Teknik Bangunan FKIP UNS

${ }^{2}$ Pembimbing 1. Chundakus Habsya

${ }^{3}$ Pembimbing 2. A. G. Tamrin
} 
perhatian, dan memfasilitasi proses pembelajaran.

Berdasarkan fungsinya, alat peraga dibedakan menjadi 3 kelompok, yaitu (Sanaky,2009) dalam Rayandra Asyhar (2011:13-14): 1). Alat peraga langsung, yaitu objek sebenarnya (real object) yang dibawa langsung ke kelas atau dikunjungi ke lokasi dan digunakan menjelaskan materi dengan memperagakan / menunjukkannya kepada peserta didik, 2). Alat peraga tak langsung, objek tiruan (model, miniatur, foto, dll.) yang digunakan untuk memperagakan materi ajar di kelas, 3). Peragaan, berupa kegiatan atau perbuatan yang dilakukan oleh pengajar di kelas untuk mendemonstrasikan suatu materi ajar yang sifatnya psikomotorik. Contoh peragaan bagaimana orang berwudhu, sholat, gerakan senam, memerankan pengemis, membaca puisi, dan lain-lain.

Berdasarkan pendapat diatas, kelompok alat peraga tak langsung adalah yang dirasa paling sesuai, karena alat peraga yang dirancang berupa model tiruan berbentuk maket yang mempunyai ukuran lebih kecil dibandingkan bentuk aslinya. Ukuran yang lebih kecil ditujukan agar alat peraga mempunyai mobilitas yang dapat dibawa kedalam kelas.

\section{METODE PENELITIAN}

Penelitian ini mengacu pada metode penelitian dan pengembangan (Research and Development), yaitu metode penelitian yang digunakan untuk menghasilkan produk tertentu, dan menguji keefektifan produk tersebut (Sugiyono, 2015:407).

Data penelitian diperoleh dari hasil observasi, dokumentasi, dan angket penilaian media pembelajaran. Sumber data diperoleh dari mahasiswa, dosen pengampu mata kuliah Konstruksi Bangunan Gedung III dan dosen ahli.

\section{Metode Pengumpulan Data}

Teknik pengumpulan data penelitian ini meliputi: observasi, angket, dokumentasi. Observasi atau pengamatan dilakukan untuk mencari data permasalahan sebelum melakukan ke tahap penelitian. Observasi dilakukan pada kelas Mata Kuliah Konstruksi Bangunan Gedung III. Angket dalam penelitian digunakan sebagai uji kelayakan. Angket ini diisi oleh tim ahli dan mahasiswa sebagai tanggapan tentang media pembelajaran berbasis alat peraga. Dokumentasi digunakan untuk melengkapi data-data dari observasi dan angket. Responden yang dilibatkan dalam pengambilan data adalah ahli materi, ahli media, ahli pembelajaran untuk uji validasi media alat peraga dan Mahasiswa Pendidikan Teknik Bangunan FKIP UNS untuk uji coba produk media.

\section{Metode Analisis Data}

Analisis penelitian ini menggunakan analisis statistik deskriptif untuk mendapatkan hasil penelitian pengembangan. Kategori kelayakan

\footnotetext{
${ }^{1}$ Mahasiswa Pendidikan Teknik Bangunan FKIP UNS

${ }^{2}$ Pembimbing 1. Chundakus Habsya

${ }^{3}$ Pembimbing 2. A. G. Tamrin
} 
media pembelajaran ini dipakai skala pengukuran skala likert. Jawaban setiap item instrumen yang menggunakan skala likert mempunyai gradasi dari sangat positif sampai sangat negatif (Sugiyono, 2013: 135).

Tabel 1. Skor Penilaian

\begin{tabular}{ll}
\hline Kategori Penilaian & Skor \\
\hline Sangat Layak & 5 \\
\hline Layak & 4 \\
\hline Cukup Layak & 3 \\
\hline Tidak Layak & 2 \\
\hline Sangat Tidak Layak & 1 \\
\hline (sumber: Sugiyono, $2013: 136$ ) \\
HASIL PENELITIAN DAN \\
PEMBAHASAN
\end{tabular}

Hasil penelitian perancangan media pembelajaran berbasis video tutorial pada mata kuliah ilmu ukur tanah II dikembangkan berdasarkan prosedur yang telah dirancang. Dalam pelaksanaannya, penelitian ini terbagi menjadi 3 tahap yaitu :

\section{a) Tahap Studi Pendahuluan}

Dalam tahap studi pendahuluan, dilakukan dengan dua cara, yaitu: studi lapangan dan studi literatur. Studi lapangan yang dilakukan oleh peneliti dengan melakukan observasi pada perkuliahan mata kuliah konstruksi bangunan gedung III. Kemudian melakukan wawancara kepada mahasiswa yang mengambil mata kuliah konstruksi bangunan gedung III, lalu mencari permasalahan yang menjadi kendala mahasiswa, salah satu permasalahan yang bisa dimunculkan adalah pada kompetensi dasar menggambar kudakuda, mahasiswa mengalami kesulitan dalam memahami materi dan dalam menggambar objek. Sebanyak 44 mahasiswa menganggap materi mendesain kuda-kuda merupakan materi yang sulit. Penggunaan alat peraga dirasa masih cukup perlu untuk mendukung mahasiswa dalam memahami bentuk kuda-kuda, dan membantu mewujudkan tujuan dan kompetensi pembelajaran.

Studi literatur yang dilakukan peneliti adalah dengan mencari referensi, pustaka, jurnal dan sumber berita alternatif pembelajaran yang mempermudah pembelajar dalam memahami sebuah objek materi kuda-kuda.

\section{b) Tahap Studi Pengembangan}

Pada tahap pengembangan, hasil dari studi literatur dan studi lapangan dibuat menjadi sebuah desain atau rancangan alat peraga maket kuda-kuda sistem bongkar pasang. Pembuatan model alat peraga maket kuda-kuda sistem bongkar pasang dimulai dengan mengajukan gambar rencana kepada dosen pengampu mata kuliah Konstruksi Bangunan Gedung III, yaitu Guntur Siamsono. Gambar kerja disesuaikan dengan teori yang ada dibuku Supribadi (1993). Gambar kerja alat peraga maket kuda-kuda ini berdasarkan standar PKKI (Peraturan

\footnotetext{
${ }^{1}$ Mahasiswa Pendidikan Teknik Bangunan FKIP UNS

${ }^{2}$ Pembimbing 1. Chundakus Habsya

${ }^{3}$ Pembimbing 2. A. G. Tamrin
} 
Konstruksi Kayu Indonesia). Desain yang diajukan peneliti meliputi: (1). kuda-kuda utuh (gambar 1), (2). hubungan kaki kuda-kuda dengan balok tarik berjumlah 4 sambungan (gambar 2), (3). hubungan kaki kudakuda dengan balok sokong berjumlah 3 sambungan (gambar 3), (4). hubungan kaki kuda-kuda dengan balok gantung berjumlah 2 sambungan (gambar 4), (5). hubungan balok kunci berjumlah 5 sambungan (gambar 5).

Tahap selanjutnya yaitu pembuatan alat peraga, bahan yang digunakan yaitu kayu jati dengan ukuran 4/6 gemuk. Peralatan yang digunakan antara lain: (1). ketam perata, (2). ketam penebal, (3). gergaji belah mesin, (4). gergaji potong mesin, (5). peralatan lukis kayu, (6). band saw, (7). bor pahat, (8). peralatan pekerjaan kayu, (9). gergaji besi, (10). gerinda mesin, (11). bor duduk, (12). mesin las.

Setelah alat peraga selesai dibuat, selanjutnya adalah tahap finishing. Proses finishing meliputi: (1). pengampelasan, (2). pengecatan dasar, (3). pengecatan ulang. Berikut ini adalah alat peraga yang telah dibuat:

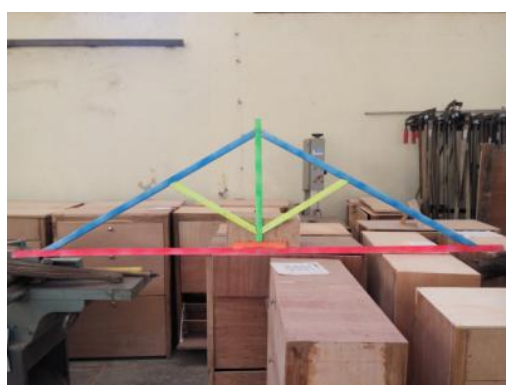

Gambar 1. Kuda-kuda Utuh

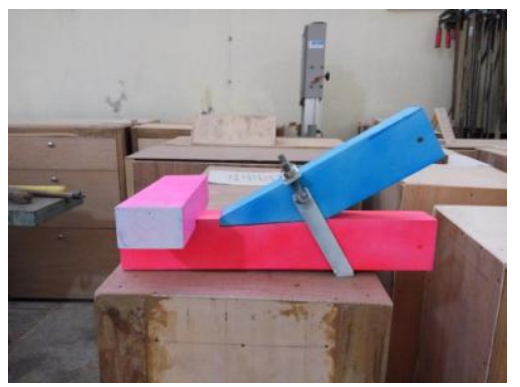

Gambar 2. Hubungan Kaki Kudakuda dengan Balok Tarik

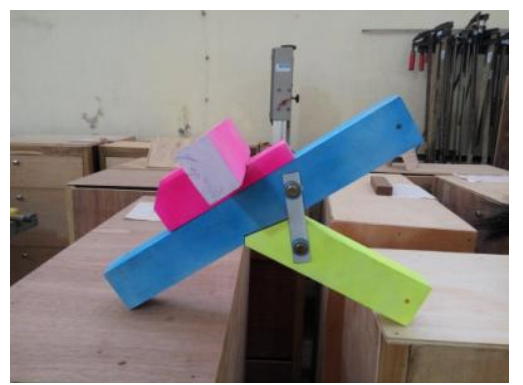

Gambar 3. Hubungan Kaki Kudakuda dengan Balok Sokong

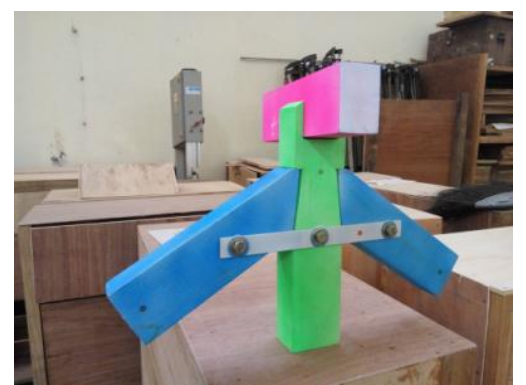

Gambar 4. Hubungan Kaki Kudakuda dengan Balok Gantung

${ }^{1}$ Mahasiswa Pendidikan Teknik Bangunan FKIP UNS

${ }^{2}$ Pembimbing 1. Chundakus Habsya

${ }^{3}$ Pembimbing 2. A. G. Tamrin 


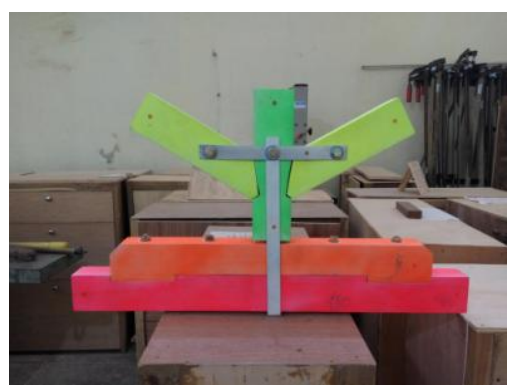

Gambar 5. Hubungan Balok Kunci

Setelah pembuatan media selesai, selanjutnya dilakukan tahap validasi tim ahli (expert judgment) dan uji coba pemakaian. Proses ini bertujuan untuk mengetahui kelayakan media pembelajaran alat peraga oleh 1 ahli materi, 1 ahli media, 1 ahli pembelajaran dan 6 mahasiswa pada uji coba terbatas dan 55 mahasiswa pada uji coba luas angkatan 2014 PTB FKIP UNS yang telah mengambil mata kuliah Konstruksi Bangunan gedung III.

Tabel 2. Penilaian Ahli Materi

\begin{tabular}{lll}
\hline No. & Aspek & Persentase \\
\hline 1. & Kesesuaian & $100 \%$ \\
\hline 2. & Ketepatan & $85,58 \%$ \\
\hline 3. & Kelengkapan & $90 \%$ \\
\hline & Jumlah & $86,09 \%$ \\
\hline
\end{tabular}

Pada Tabel 2. menampilkan hasil penilaian oleh ahli materi. Tingkat kelayakan media pembelajaran berdasarkan penilaian dari ahli materi yaitu sebesar 86,09 \%. Media pembelajaran termasuk dalam kategori kelayakan yaitu sangat layak.
Tabel 3. Penilaian Ahli Media

\begin{tabular}{lll}
\hline No. & Aspek & Persentase \\
\hline 1. & Tahan Lama & $94,828 \%$ \\
\hline 2. & Bentuk Menarik & $80 \%$ \\
\hline 3. & Warna Menarik & $80 \%$ \\
\hline 4. & Sederhana & $100 \%$ \\
\hline 5. & Mudah Digunakan & $100 \%$ \\
\hline 6. & $\begin{array}{l}\text { Realistik } \\
\text { (Konkret) }\end{array}$ & $100 \%$ \\
\hline & Jumlah & $93,571 \%$ \\
\hline
\end{tabular}

Pada Tabel 3. menampilkan hasil penilaian oleh ahli media. Tingkat kelayakan media pembelajaran sebesar 93,571 \%. Media pembelajaran termasuk dalam kategori kelayakan yaitu sangat layak.

Tabel 4. Penilaian Ahli Pembelajaran

\begin{tabular}{lll}
\hline No. & Aspek & Persentase \\
\hline 1. & $\begin{array}{l}\text { Kualitas Isi dan } \\
\text { Tujuan }\end{array}$ & $90 \%$ \\
\hline 2. & $\begin{array}{l}\text { Kualitas } \\
\text { Pembelajaran }\end{array}$ & $92,308 \%$ \\
\hline & Jumlah & $91,765 \%$ \\
\hline
\end{tabular}

Pada Tabel 4. menampilkan hasil penilaian oleh ahli pembelajaran. Tingkat kelayakan media pembelajaran sebesar 91,765\%. Media pembelajaran termasuk dalam kategori kelayakan yaitu sangat layak.

${ }^{1}$ Mahasiswa Pendidikan Teknik Bangunan FKIP UNS

${ }^{2}$ Pembimbing 1. Chundakus Habsya

${ }^{3}$ Pembimbing 2. A. G. Tamrin 
Tabel 5. Rekapitulasi Uji Coba Terbatas

\begin{tabular}{lll}
\hline No. & Aspek & Persentase \\
\hline 1. & Kualitas Teknis & $63,333 \%$ \\
\hline 2. & $\begin{array}{l}\text { Kualitas } \\
\text { Pembelajaran }\end{array}$ & $62,917 \%$ \\
\hline & Jumlah & $63 \%$ \\
\hline
\end{tabular}

Pada Tabel 5. menampilkan hasil rekapitulasi uji coba terbatas. Uji coba terbatas sebanyak 6 mahasiswa yaitu sebesar $63 \%$. Media pembelajaran termasuk dalam kategori kelayakan yaitu layak.

Tabel 6. Rekapitulasi Uji Coba Luas

\begin{tabular}{lll}
\hline No. & Aspek & Persentase \\
\hline 1. & Kualitas Teknis & $87,6 \%$ \\
\hline 2. & Kualitas & $83,55 \%$ \\
& Pembelajaran & \\
\hline & Jumlah & $84,36 \%$ \\
\hline
\end{tabular}

Pada Tabel 6. menampilkan hasil rekapitulasi uji coba luas. Uji coba luas sebanyak 50 mahasiswa yaitu sebesar 84,36 \%. Media pembelajaran termasuk dalam kategori kelayakan yaitu sangat layak.

\section{c) Tahap Evaluasi}

Dalam tahap ini, media pembelajaran telah melalui proses validasi oleh ahli materi, ahli media dan ahli pembelajaran, kemudian dilaksanakan uji coba terhadap mahasiswa. Hasil akhir dari media pembelajaran berbasis alat peraga ini adalah produk media beserta kelebihan dan kekurangannya.

\section{Kajian Produk}

Hasil penelitian yang telah dilakukan menunjukkan bahwa media pembelajaran yang dikembangkan layak untuk digunakan dalam proses pembelajaran. Hal ini ditunjukkan dengan diperolehnya data - data yang telah memenuhi syarat sebagai media yang layak. Media pembelajaran yang dikembangkan adalah alat peraga maket kuda-kuda system bongkar pasang pada mata kuliah Konstruksi Bangunan Gedung III. Berdasarkan hasil evaluasi dari tim ahli dan uji coba pemakaian, media pembelajaran yang dikembangkan memiliki kelebihan diantaranya sebagai berikut:

1. Warna yang digunakan alat peraga sangat menarik perhatian.

2. Setiap batang kuda-kuda mempunyai warna yang berbeda, berguna untuk menunjukkan fungsi peranan batang dalam konstruksi.

3. Knock Down System lebih disukai pembelajar.

4. Media Pembelajaran berupa benda konkrit yang tidak hanya bisa dilihat, tetapi juga bisa dipegang dan dioperasikan.

5. Media pembelajaran tidak membutuhkan energi listrik.

6. Media pembelajaran mampu menghilangkan verbalisme materi.

\footnotetext{
${ }^{1}$ Mahasiswa Pendidikan Teknik Bangunan FKIP UNS

${ }^{2}$ Pembimbing 1. Chundakus Habsya

${ }^{3}$ Pembimbing 2. A. G. Tamrin
} 
Kekurangan media pembelajaran berbasis alat peraga system bongkar pasang sebagai berikut:

1. Alat peraga mempunyai massa yang berat karena menggunakan bahan dasar kayu.

2. Tingkat presisitas ukuran alat peraga masih rendah, karena proses pengerjaan masih tergolong sulit.

\section{KESIMPULAN}

Berdasarkan hasil penelitian dan pembahasan sebelumnya, peneliti dapat menyimpulkan sebagai berikut:

1. Prosedur pengembangan media pembelajaran berbasis alat peraga maket kuda-kuda sistem bongkar pasang pada mata kuliah konstruksi bangunan gedung III dibagi menjadi beberapa tahap, yaitu:

a. tahap studi pendahuluan

b. tahap pengembangan

1) perancangan media pembelajaran

2) validasi media pembelajaran oleh tim ahli

3) revisi dan perbaikan dari tim ahli

4) uji coba terbatas

5) revisi dan perbaikan uji coba terbatas

6) uji coba luas

7) revisi dan perbaikan uji coba luas

c. tahap evaluasi berupa model final beserta kelebihan dan kelemahan media pembelajaran.
2. Kelayakan media pembelajaran berdasarkan penilaian ahli materi sangat layak (skor 86,09\%), penilaian ahli media sangat layak (skor 93,571\%), penilaian ahli pembelajaran sangat layak (skor 91,765\%), uji coba terbatas layak (skor 63\%), dan uji coba luas sangat layak (skor $84,36 \%$ ).

\section{SARAN}

Berdasarkan hasil penelitian dan pembahasan sebelumnya, peneliti dapat memberikan saran sebagai berikut:

Penggunaan alat peraga dalam pembelajaran sebaiknya digunakan pada awal materi pembelajaran.

Perangkat alat peraga ini bersifat membantu proses pembelajaran dengan menghilangkan verbalisme, bukan menggantikan model pembelajaran.

Media pembelajaran alat peraga yang dibuat pada mata kuliah konstruksi bangunan gedung III dapat diperluas ke materi-materi lain tidak hanya pada konstruksi kuda-kuda.

Dalam pengembangan selanjutnya, sebaiknya bahan baku pembuatan alat peraga terbuat dari bahan plastic/nilon.

\section{DAFTAR PUSTAKA}

Anitah, Sri. (2008). Media Pembelajaran. Surakarta: UNS Press.

${ }^{1}$ Mahasiswa Pendidikan Teknik Bangunan FKIP UNS

${ }^{2}$ Pembimbing 1. Chundakus Habsya

${ }^{3}$ Pembimbing 2. A. G. Tamrin 
Asyhar, Rayandra. (2011). Kreatif Mengembangkan Media Pembelajaran. Jakarta: Gaung Persada Press.

Daryanto. (2013). Media Pembelajaran. Yogyakarta: Gava Media.

Herdiansyah, Haris. (2013). Wawancara, Observasi, dan Focus Groups: Sebagai Instrumen Penggalian. Jakarta: Rajawali Pers.

Koesnandar, Ade. (2003). Teknodik. Pustekkom Depdiknas. Volume VII No.13.

Kustandi, Cecep. (2013). Media Pembelajaran Manual dan Digital. Bogor: Ghalia Indonesia.

Puspantoro, Benny. (1992). Konstruksi Bangunan Gedung Tidak Bertingkat. Yogyakarta: Andi Offset.

Sanaky, Hujair AH. (2009). Media Pembelajaran. Yogyakarta: Safira Insania Press.

Sugiyono. (2015). Metode Penelitian Pendidikan. Bandung: Alfabeta. , (2015). Metode Penelitian dan Pengembangan. Bandung: Alfabeta.

Sukiman. (2012). Pengembangan Media Pembelajaran. Yogyakarta: Pedagogia.

Sundayana, Rostiana. (2013). Media Pembelajaran Matematika. Bandung: Alfabeta.

${ }^{1}$ Mahasiswa Pendidikan Teknik Bangunan FKIP UNS

${ }^{2}$ Pembimbing 1. Chundakus Habsya

${ }^{3}$ Pembimbing 2. A. G. Tamrin 